\title{
FENOMENOLOGIA I AGATOLOGIA
}

\author{
Rozważając cel filozofowania, należy dążyć do tego, by \\ myślenie o człowieku opuściło płytkie wody psychologi- \\ zmu i wptynęło na głębię agatologii. \\ J. Tischner, Wstęp do filozofii osoby ${ }^{1}$
}

W prezentowanym artykule centrum organizujące przedstawiane rozważania stanowi twierdzenie, iż związek fenomenologii i agatologii, uwyraźniający się w myśleniu Tischnera, decyduje o specyfice jego filozofii. Podkreślmy, że w Tischnerowskim filozofowaniu badawcza perspektywa fenomenologii i rozważania natury agatologicznej pozostają ze sobą ściśle związane. Po dokonaniu redukcji fenomenologicznej zmieniamy nastawienie i wkraczamy na poziom transcendentalno-fenomenologiczny, poziom, w którego świetle możliwe staje się odsłonięcie agatologicznego wymiaru podmiotowości. Prezentowane $\mathrm{w}$ niniejszym artykule twierdzenie rozpatrzymy w postaci dwóch tez: po pierwsze, to właśnie wychodząc od koncepcji "ja" transcendentalnego, Tischner, który rozpoczyna swe filozofowanie od analiz fenomenologii Husserla, szczególnie fenomenologii egotyczności, rozwija koncepcję „ja" aksjologicznego i "ja" agatologicznego; po drugie, koncepcję istoty dramatycznej można rozumieć jako rezultat namysłu nad Husserlowskim ujęciem podmiotowości. W prezentowanych rozważaniach rozpatrzymy po krotce właśnie te zaanonsowane kwestie.

Przyjęcie fenomenologicznego punktu wyjścia nie oznacza dla Tischnera - kroczącego za Husserlem - popadnięcia w dogmatyzm, lecz wręcz przeciwnie - nieskończone otwarcie, któremu towarzyszy wymóg krytycznego

${ }^{1} \mathrm{~J}$. Tischner, Wstep do filozofii osoby, [w:] „Fermentum massae mundi”. Jackowi Wożniakowskiemu $w$ siedemdziesiąta rocznice urodzin, red. N. Cieślińska, P. Rudziński, Warszawa 1990, s. 226. 
rozumowania oraz wartościowania. Nasuwa się pytanie: na czym opiera się to wartościowanie, co stanowi jego kryterium? Według Tischnera, podstawę tę stanowi Husserlowska „idea człowieczeństwa, której jednak nie otrzymujemy w darze z zaświatów", ale która daje się dzięki i d e a l i z a c j i wyczytać z ludzkiego doświadczenia ${ }^{2}$. W ujęciu Tischnera, "ja” konstytuuje się według logosu dobra i zła, tworząc szczególny zespół sensów subiektywnych, czyli ludzką osobowość. Znamienne wydają się, według Tischnera, słowa Husserla: „W każdej duszy ludzkiej spoczywa - jak wierzę - możliwe do rozwinięcia powołanie, zarodek ku dobru. W każdym leży zamknięte idealne Ja, «prawdziwe» Ja jako osoby, która urzeczywistnia się jedynie w «dobrym» działaniu. Każdy etycznie dorosły człowiek zakłada w samym sobie swe idealne Ja jako «nieskończone zadanie»"3.

\section{I}

Podejmując rozważania dotyczące pierwszej rozważanej tezy, głoszącej, iż właśnie wychodząc od koncepcji ,ja” transcendentalnego, Tischner, który rozpoczyna swe filozofowanie od analiz fenomenologii Husserla, szczególnie fenomenologii egotyczności, rozwija koncepcję "ja" aksjologicznego i „ja” agatologicznego, warto uwyraźnić raz jeszcze centralne, udowadniane $\mathrm{w}$ niniejszym artykule generalne przekonanie, iż rozważania dotyczące perspektywy dobra wymagają - podobnie jak $\mathrm{w}$ fenomenologii Husserla - usytuowania rozważań w innym wymiarze, wymiarze aksjologiczno-agatologicznym. Przyjąwszy fenomenologiczny punkt widzenia, Tischner stwierdza: „[...] wystarczy, jeśli zobaczymy, że realny świat nie jest światem «absolutnym», lecz «relatywnym», to znaczy światem wcale nie jedynym z możliwych"4. „Prawdziwe życie - powtarza dobitnie w Filozofii dramatu - jest nieobecne" 5 . W ujęciu Tischnera, w stronę tego wymiaru zwrócone jest - zorientowane na dobro - „ja” agatologiczne, które wyznacza szczytowy punkt filozofii dramatu.

W swej rozprawie doktorskiej Ja transcendentalne w filozofii Edmunda Husserla Tischner nawiązuje do poglądów twórcy fenomenologii dotyczących zagadnienia wewnętrznej budowy świadomości transcendentalnej. „W poglądach na zagadnienie budowy świadomości - pisze we wstępie rozprawy - interesuje nas szczególnie to, co dotyczy jej «subiektywnego bieguna»,

\footnotetext{
2 Por. J. Tischner, Fenomenologia a socjologia, "Znak” 1977, nr 9, s. 1052.

${ }^{3}$ E. Husserl, Zur Phänomenologie der Intersubjektivität, [cyt. za:] J. Tischner, op. cit., s. 1052.

4 J. Tischner, op. cit., s. 1053.

${ }^{5}$ J. Tischner, Filozofia dramatu, Paris 1990, s. 58.
} 
który Husserl nazywał «ja» transcendentalnym" ${ }^{\prime \prime}$. Koncepcja „ja” transcendentalnego staje się nie tylko problemowym punktem wyjścia, od którego rozpoczyna rozważania polski badacz, lecz przede wszystkim możliwością otwierającą przed nim horyzont potencjalnych analiz, wyznaczającą kierunek poszukiwań. Już w ostatniej części pracy doktorskiej autor rozprawy Ja transcendentalne... odsłania nieujawniony dotąd przez Husserla wymiar ego, nową perspektywę badawczą, i tym samym anonsuje projekt własnego rozumienia koncepcji „ja" transcendentalnego, projekt będący jego twórczym wkładem w rozwój problematyki fenomenologicznej. Pisze wprost: "gdy świadomość zetknie się z «kruchością» tego, kogo jest świadomością, ujawniają się przed nią momenty tragizmu"7. Zdaniem Tischnera, problem "ja", ściślej: problem jego istnienia w sferze świadomości, otwiera "nową sferę badań nad człowiekiem" 8 .

Kontynuując ten wątek myślowy, autor rozprawy Ja transcendentalne... stwierdza dalej, iż w ramach badań nad świadomością transcendentalną można, podejmując próbę „wskrzeszenia przynajmniej niektórych z wielkich zagadnień tradycyjnej filozofii", zająć się problematyką szeroko pojętej "duchowości" 9 . Stąd wniosek, że "ja" transcendentalne niejako "anonsuje" Tischnerowski projekt „ja” aksjologiczno-agatologicznego. Jeśli bowiem rozpatrzy się aksjologiczny aspekt "ja" transcendentalnego, to okazuje się, że - jak pokaże Tischner dziesięć lat później - jest ono ,ja” aksjologicznym. W wyniku rozwinięcia koncepcji egotyczności, polski filozof uwzględnia pierwotne, podstawowe cechy , ,ja”: „konscjentywność” oraz „aksjologiczność". Sfera egotyczności jest sferą konscjentywną, zawierająca w sobie wszelkie możliwe oraz faktyczne treści, jest przestrzenią egotycznie pierwotną, w której rozpoczyna się oraz zachodzi sa mokonstytucja "ja". Okazuje się zatem, że transcendentalny charakter sfery świadomości można scharakteryzować, posługując się określeniami tych cech, które tę sferę znamionują, cech, które dane jej od razu, odzwierciedlają jej pierwotny charakter. W rezultacie rozwinięcia aksjologicznego wątku ,ja" transcendentalnego oraz dopełnienia myśli Husserla - przeniesienia rozważań na poziom myślenia religijnego - w swej Filozofii dramatu polski filozof pokazuje, że w świetle dialogicznego otwarcia na dobro, łaskę, na Boga, na drugiego, "ja" aksjologiczne odsłania się w horyzoncie dobra jako „ja” agatologiczne.

${ }^{6}$ J. Tischner, Ja transcendentalne w filozofii Edmunda Husserla, [w:] idem, Studia z filozofii świadomości, Kraków 2006, s. 3.

${ }^{7}$ Ibidem, s. 122.

8 Ibidem.

${ }^{9}$ Zob. ibidem. 
Filozofia Tischnera, łącząca badawczą perspektywę fenomenologii z refleksją par excellence agatologiczno-aksjologiczną, przemawia do świadomości i pobudza do myślenia według wartości. Można się pokusić o twierdzenie, że praca Tischnera, w której posługuje się on metodą fenomenologiczną, powstaje jako rezultat rozwinięcia aksjologicznej perspektywy fenomenologii. „Chrześcijaństwo - stwierdza Tischner - jako wydarzenie we wnętrzu nadziei jest szczególnie bliskie duchowi współczesnego świata. Chodzi tylko o to, by znów uświadomiło sobie ono, że jest «wydarzeniem», które ma przemówić do nadziei, bo się z nadzieją poczęło"10. Siła fenomenologii, która powstaje jako odpowiedź na pytanie wyłaniające się $\mathrm{z}$ określonego momentu dziejowego, z kryzysu nauki, jest - zdaniem autora Filozofii dramatu bardziej siłą moralną niż siłą ściśle teoretyczną ${ }^{11}$.

$\mathrm{Na}$ podstawie analiz przeprowadzonych $\mathrm{w}$ niniejszym opracowaniu można sformułować wniosek, że filozofia dramatu to znacznie więcej niż antropologia - to agatologia, fenomenologia dobra, którego doświadcza "ja” będące wartością. Podejmując zagadnienia z pogranicza problematyki nauki o człowieku, filozofii świadomości, aksjologii, etyki oraz duchowości, Tischner rozwija koncepcję fenomenologii transcendentalnej, która - jak trafnie pisze Jean-François Lyotard - „zmierza nie do zastąpienia nauk o człowieku, ale do dopracowania ich problematyki, poddając przy tym selekcji ich wyniki i ukierunkowując na nowo ich badania"12. Nie można pominąć faktu, że w pewnej mierze ujęcie wypracowane przez Tischnera zostało zaanonsowane przez samego Husserla $w$ ramach projektu fenomenologii transcendentalnej.

\section{II}

Przejdźmy teraz do tezy kolejnej, w której zasadności i jasności nabiera fakt, że to właśnie w rezultacie aksjologiczno-agatologicznej interpretacji Husserlowskiej koncepcji podmiotowości, podmiotowości rozpatrywanej w kontekście związanego z nią paradoksu, Tischner pojmuje osobę jako istotę dramatyczną. Jak zostało już zaznaczone, w niniejszym artykule uznajemy, iż rozważania dotyczące perspektywy dobra wymagają przekroczenia poziomu nastawienia naturalnego $\mathrm{i}$ - podobnie jak $\mathrm{w}$ fenomenologii Husserla - usytuowania ich w innym wymiarze, wymiarze aksjologiczno-agatologicznym.

\footnotetext{
${ }^{10}$ J. Tischner: Wiazania nadziei. „Znak” 1973, nr 9, s. 1118.

11 Por. J. Tischner, Filozofia dramatu..., op. cit., s. 77.

12 J.-F. Lyotard, Fenomenologia, tłum. J. Migasiński, Warszawa 2000, s. 10.
} 
W Filozofii dramatu, łącząc rozważania filozoficzne $\mathrm{z}$ namysłem nad wewnętrznym życiem osoby, Tischner nie rezygnuje $z$ fenomenologicznej perspektywy badawczej. W swej ostatniej pracy, wykorzystując metodę fenomenologiczną, formułuje aksjologiczno-agatologiczne reguły. Całość dyrektyw dotyczących różnych poziomów aksjologicznego wymiaru życia egotycznego określa mianem „agatologiczno-aksjologicznych reguł uczestnictwa w dramacie", regul, które związane są z " «logiką» tego, co jest «poza bytem i niebytem» - logiką transcendentaliów"13. W swej Filozofii dramatu daje wyraz przekonaniu, że myślenie według wartości powinno być myśleniem agatologicznym, otwartym na dobro. $Z$ takiego punktu widzenia filozoficzny zamysł Tischnera nie jest swobodną refleksją, lecz krytycznym myśleniem, wysiłkiem, jaki zadaje sobie autor w celu ukazania drogi ocalenia od tragedii, na którą jest narażona istota dramatyczna. Zgodnie z wizją Tischnera: „osoby uczestniczące w dramacie widzą i rozumieją siebie w perspektywie aksjologicznej i agatologicznej. Ich myślenie jest myśleniem według wartości. W oparciu o nie «uciekają» od zła i dążą do dobra. Zwycięstwo zła uważają za tragedię"14.

Za jedno z najbardziej znaczących twierdzeń zawartych w Filozofii dramatu należy uznać tezę, że aksjomatem dramatu jest dobro ${ }^{15}$. „Nie jest to jednak - pisze Tischner - żaden założony z góry aksjomat rozumu, przeciwko któremu nie można wątpić. Dobro, jeśli naprawdę ma być dobrem, nie może być wyrozumowane, lecz musi być doświadczone"16. Przyjąwszy fenomenologiczny punkt widzenia, Tischner stwierdza, iż źródłowe doświadczenie drugiego sprawia, że rozbudzona zostaje aksjologiczna problematyczność utrwalonego dotychczas obrazu otaczającego świata i siebie samego, jako istniejącego w nim ,ja”, problematyczność powodująca wytrącenie "ja" z jego dotychczasowego sposobu życia.

Według autora Filozofii dramatu, doświadczeniem par excellence jest „doświadczenie innego człowieka - spotkanie z innym"17, które otwiera przed doświadczającym go ,ja" nowy wątek dramatyczny, u którego początku znajduje się "ziarno dobroci obudzonej w człowieku przez dobro"18. Spotkanego człowieka Tischner przyrównuje do źródła światła, które "promieniuje przede wszystkim do wnętrza, odsłaniając tam niewidzialne na co dzień doznania i uczucia. [...] Światło wydobywa na jaw nieuchwytny

\footnotetext{
${ }_{13}$ Zob. J. Tischner, Filozofia człowieka dla duszpasterzy i artystów, Kraków 1991, s. 21.

${ }^{14}$ Ibidem, s. 16.

${ }^{15}$ Zob. J. Tischner, Filozofia dramatu..., op. cit., s. 91.

16 Ibidem.

17 Zob. ibidem, s. 27

${ }^{18}$ Zob. ibidem, s. 51.
} 
$\mathrm{w}$ innych sytuacjach zwrot człowieka ku samemu sobie odczuwany jako zdziwienie sobą, ku nieznanemu przedtem bogactwu, którego istnienie uświadamia człowiekowi inny człowiek"19. Dzięki spotkaniu otwiera się nieograniczony horyzont, nadmiar sensu, nad którym nie panuje „ja” poznające. Międzyosobowa więź okazuje się zarazem wymiarem warunkującym stawanie się samoświadomości. Źródłowe doświadczenie drugiego powoduje, że w wyniku zetknięcia z wartością, wymagającą wzbudzenia aktu etycznego, ,ja" doznaje przebudzenia, odsłania siebie w świetle dobra, stając się "ja" agatologicznym. Z fenomenologicznego punktu widzenia, "ja” agatologiczne to "ja" doświadczające siebie w horyzoncie dobra. W Filozofii dramatu Tischner, wychodząc od doświadczenia agatologicznego, nadaje tym samym ,ja" aksjologicznemu sens agatologiczny.

Dramat to nic innego jak rozdźwięk, jakiego doświadcza "ja" między swym życiem w świecie naturalnym a przeżyciem siebie jako wartości w horyzoncie dobra. Analiza źródłowego doświadczenia dobra lub zła doświadczenia agatologicznego, roztaczającego przed „,ja" nowy horyzont umożliwia Tischnerowi nie tylko ukazanie międzypodmiotowej więzi, lecz przede wszystkim dotarcie do samej istoty egotyczności, którą stanowi jej aksjologiczne udramatyzowanie. "Ja" jest bowiem z jednej strony transcendentalną, agatologiczno-aksjologiczną potencjalnością, która, z drugiej strony, urzeczywistnia się jako „ja” osobowe (,ja” społeczne) w świecie nastawienia naturalnego.

Rozdźwięk ten, wpisany w egzystencję człowieka, związany jest z paradoksem podmiotowości, o którym pisze Husserl. Twórca fenomenologii formułuje paradoks podmiotowości w kontekście konstytucji sensu. Ten paradoks można sformułować w postaci pytania: jak jest możliwe, że „ja” jest $\mathrm{w}$ świecie, a zarazem konstytuuje świat? Koncentrując się na przedmiotowym wymiarze konstytucji, Husserl pomija, zdaniem Tischnera, aksjologiczny moment egotyczności. Podejmując ten wątek, Tischner interpretuje „ja" oraz związany z nim paradoks w kategoriach aksjologicznego dramatu ludzkiej egzystencji, dramatu ,ja”, które urzeczywistniając siebie jako aksjologiczną potencjalność, ograniczone jest jednak skończonością i kruchością własnej natury. $W$ ujęciu Tischnera, paradoks subiektywności nie dotyczy konstytucji sensu, lecz rozgrywa się $\mathrm{w}$ sferze wartości. $\mathrm{W}$ ramach swego filozoficznego zamysłu Tischner pojmuje i charakteryzuje nastawienie transcendentalne jako aksjologiczno-agatologiczne nastawienie ",ja", a w konsekwencji rozdźwięk między nastawieniem naturalnym a transcendentalnym ujmuje on jako rozdźwięk między postawą naturalną a postawą aksjologicz-

19 Ibidem, s. 94. 
no-agatologiczną. Dramat dotyczy rozdźwięku między naturalnymi skłonnościami człowieka, który jest bytem skończonym, a aksjologiczno-agatologicznym wymiarem, w którym funkcjonuje transcendentalne ,ja". Dramat jest $\mathrm{w}$ istocie permanentnym konfliktem panującym $\mathrm{w}$ sferze egotycznej, rozdarciem między grożącą "ja" tragedią a nadzieją na ocalenie, między własnymi faktycznymi skłonnościami, wynikającymi ze skończoności jego natury, a ukrytą w nim i zarazem realizowaną przez nie jego aksjologicznoagatologiczną potencjalnością. Koncepcję istoty dramatycznej, ujmowanej jako ",ja" aksjologiczno-agatologiczne, można rozumieć jako rezultat namysłu nad Husserlowskim ujęciem podmiotowości i związanym z nim paradoksem, w ramach którego człowiek jest osobą żyjącą w permanentnym rozdźwięku: pozostaje bowiem jednocześnie osobą żyjącą $\mathrm{w}$ nastawieniu naturalnym, jak również zawsze "ja" transcendentalnym. Oczywiste dotąd istnienie na scenie jawi się od tej chwili jako rozpięte między dobrem i złem, ocaleniem i tragedią, wartością i antywartością.

Rozdarcie to, przybierające postać aksjologiczno-agatologicznego rozdźwięku, sprawia, że istnienie własnego "ja", które traci nagle swą oczywistość, staje się problematyczne. Dramatyczne położenie „ja" rozpoczyna się z chwilą, gdy odsłaniając siebie jako "ja" agatologiczne (w horyzoncie agatologicznym), nie może ono powrócić do swego dotychczasowego sposobu zaangażowania $\mathrm{w}$ świat. Wskutek takiego rozdźwięku rozpada się nie tylko dotychczasowy obraz świata, lecz także układ wartości osobistych. Mając na uwadze myśl organizującą wątki dramatyczne, jaką ewokuje pytanie o Boga, Filozofia dramatu okazuje się pracą dotykająca problemu wewnętrznego napięcia, aksjologiczno-agatologicznego dramatu toczącego się wewnątrz „ja”, które odpowiada swym życiem na wezwanie Boga. Przenosząc fenomenologiczny paradoks podmiotowości na poziom aksjologiczno-agatologiczny, Tischner pokazuje, że w zależności od wyboru wartości pozytywnej lub negatywnej, ,ja" może być albo istnieniem dobra, albo istnieniem zła: „dla człowieka - pisze - samo istnienie jest problemem. Jest nim zaś tylko dlatego, że może ono być zarówno istnieniem dobra, jak i istnieniem zła" 20 .

Odczytanie Filozofii dramatu przez pryzmat jej początku, jaki stanowią fenomenologiczne analizy dotyczące "ja", naprowadza na twierdzenie, że ego, które nadaje sens otaczającemu je światu, samo kształtuje się zarazem

${ }^{20}$ Ibidem, s. 155 . 
pod wpływem tego, co obiera za przedmiot i jednocześnie cel swej konstytucji. Warunkiem dynamizmu świadomości okazuje się rozdarte między aktualnością (faktycznością) i aksjologiczną potencjalnością „ja”, które urzeczywistniając się poprzez wybór wartości, jest tym samym istotą dramatyczną. Świat to scena, na której skończone, a zarazem otwierające się na Boga, przeżywające nieustanny rozdźwięk ,ja" realizuje się w świecie w perspektywie wezwania przez Dobro, do którego urzeczywistniania zostało powołane.

\section{Phenomenology and Agathology}

\section{Summary}

The aim of this article is to prove the thesis that relation between phenomenology and agathology - as presented in Józef Tischner's work - is essential to his philosophy. Two assumptions are discussed here in order to prove main point. First, that by beginning from Husserlian concept of transcendental ' $\mathrm{I}$ ' and grounding his thought in phenomenological analysis, Tischner develops his idea of axiological and agathological 'I'. Second, Tischner's concept of 'dramatic entity' can be understood as a result of his reflection on Husserlians approach to subjectivity. As it is shown, acceptation of phenomenological point of departure doesn't cause - for Tischer who follows Husserl - to fall into a dogmatism, but, in contrary, to reveal axiologically-agathological perspective. 